\title{
Festschrift vir Hans du Plessis
}

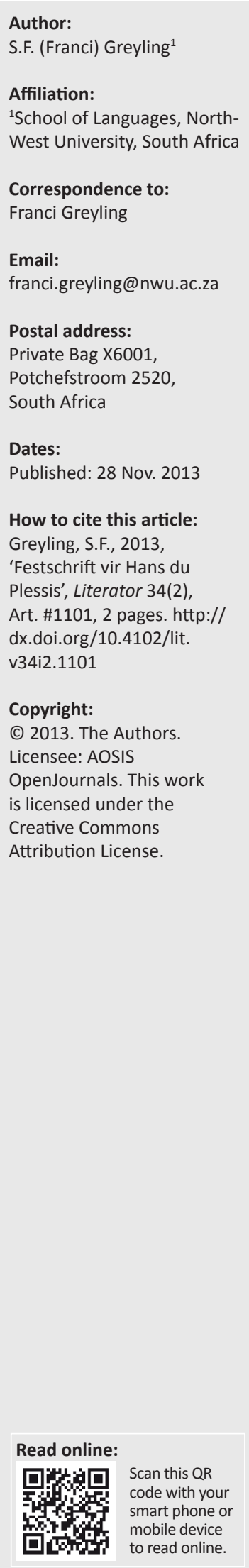

Hierdie nommer van Literator word opgedra aan Hans du Plessis, wat aan die einde van 2011 afgetree het aan die Noordwes-Universiteit se Potchefstroomkampus. In 'n loopbaan wat strek oor 46 jaar, het hy diep spore getrap as navorser, dosent, skrywer en kultuurleier.

Hans du Plessis begin sy loopbaan as hoërskoolonderwyser. In 1971 word hy aangestel as lektor aan die Universiteit van Suid-Afrika (UNISA); daarna as senior lektor by die Randse Afrikaanse Universiteit (RAU). In 1981 word hy professor in Afrikaanse Taalkunde aan die Potchefstroomse Universiteit vir Christelike Hoër Onderwys (PU vir CHO).

As taalkundige het hy hom verdiep in Algemene Taalwetenskap en in taalvariasie met betrekking tot Afrikaans. In die besonder is hy as navorser geboei deur die Afrikaans van die Griekwas. Met hierdie werk lewer hy - in die woorde van Erika Terblanche in die skrywersprofiel oor hom op LitNet - "n belangrike bydrae om Afrikaans van sy historiese en politieke beperkinge te bevry'.

Sedert 1985 is Hans betrokke by skryfkursusse wat die Afrikaanse Taal- en Kultuurvereniging (ATKV) saam met die Departement Afrikaans en Nederlands aan die PU vir CHO aanbied. Hieruit volg die stigting van die ATKV-skryfskool in 1990 aan wat nou die Noordwes-Universiteit se Potchefstroomkampus heet, met hom as die eerste direkteur. Dit is hierdie betrekking wat hy tot sy aftrede beklee het, en waardeur hy baanbrekerswerk in skryfopleiding in Suid-Afrika verrig het.

As dosent, studieleier en promotor het Hans du Plessis talle universiteitstudente tot selfstandige navorsers en skrywers begelei. As direkteur van die Skryfskool, en deur die aanbieding van 'n menigte jaarlikse en geleentheidskursusse in hierdie hoedanigheid, is skryfopleiding aan mense uit diverse ouderdomsgroepe en samelewingsverbande gebring tot hulle begeestering en toerusting.

Hans du Plessis se produktiewe skrywersloopbaan omvat meer as 160 akademiese en skeppende-skryfwerkpublikasies. Akademiese publikasies sluit in taalkundehandboeke en taal- en letterkunde-artikels in nasionale en internasionale tydskrifte. Hy debuteer in 1978 as skeppende skrywer met die digbundel Kleinwild; sedertdien het ses digbundels, drie jeugromans, vyf romans, kortverhale en talryke rubrieke onder sy naam verskyn. Ses verhoogstukke uit sy pen is by verskillende kunstefeeste opgevoer. Sy skeppende skryfwerk hou dikwels verband met sy navorsing en belangstelling in taal en taalverskeidenheid, soos met die transponering van Psalms in die taal en kultuur van Griekwa-Afrikaanssprekers in die bekroonde digbundel Innie skylte vannie Jirre. Bekronings vir sy skeppende skryfwerk is onder meer die C.R. Swart-prys vir tienertoneel, die ATKV-kinderboekprys, 'n erepenning van die S.A. Akademie en die CBSA-prys vir die beste publikasie in algemene Christelike literatuur.

Deur sy betrokkenheid in taal- en kultuurorganisasies lewer Hans du Plessis verdere belangrike bydraes. Tussen 1985 en 2010 dien hy in verskeie komitees en direksies, waaronder in die Taalkommissie en die Taalbeplanningskommissie van die S.A. Akademie, as voorsitter van die Taalkomitee en lid van die Hoofbestuur van die FAK; vise-voorsitter en voorsitter van die ATKVdireksie; voorsitter van die direksie van Lapa-uitgewers en in die direksie van die Aardklop Nasionale Kunstefees. Hy was ook lid van die Artes-beoordelaarspaneel en van die CNApryskomitee vir Letterkunde, asook lid van die hoofbestuur van die Afrikaanse Skrywersgilde. Ná sy aftrede word hy voltyds skrywer en navorsingsgenoot in die Navorsingseenheid vir Tale en Literatuur in die Suid-Afrikaanse konteks van die Noordwes-Universiteit, Potchefstroomkampus.

Die artikels in hierdie spesiale nommer van Literator reflekteer iets van die veelsydige loopbaan, bydraes en belangstellings van Hans du Plessis.

Christo van Rensburg, 'n navorsingsgenoot van Hans du Plessis sedert hulle eerste navorsingsprojek oor Oranjerivier-Afrikaans, ondersoek die belangrikheid van taal in die 
kontaksituasie in die binnelandse Grensgebied in sy artikel, "n Perspektief op 'n periode van kontak tussen Khoi en Afrikaans'. Ter illustrasie word een van die gevolge van hierdie taalkontak en gepaardgaande normverandering bespreek, te wete die Khoi-gebruik van 'ons' in die onderwerpsposisie en die inskakeling daarvan by algemeen erkende Afrikaans.

Hans du Plessis het sy akademiese loopbaan begin as taalkundige, en hom oor tyd gewend tot die skryfkuns. Dit verteenwoordig egter nie só 'n groot dissiplinesprong nie, want 'n goeie kennis van taalkunde kan versterkend wees vir 'n skrywer se skryfwerk of vir die verstaan van die skryfkunswetenskap. Dit is daarom gepas dat daar hierdie uitgawe ook'n bydrae bevat wat Afrikaanse skryfkunsriglyne vanuit 'n taalkunde-perspektief benader, en wat sodoende 'n verklaring probeer gee vir die ontstaan van 'n bepaalde, skynbaar redelik unieke skryfkunstradisie in Afrikaans, naamlik die 'hedetyd-skryfkunstradisie'. Adri Breed stel hierdie onderwerp aan die bod in haar artikel, 'Die hedetyd is iets van die verlede: ' $n$ Taalkundige motivering vir die "hedetydskryfkunstradisie" in Afrikaans'.

Die groei van Skryfkuns as dissipline aan Suid-Afrikaanse universiteite sluit aan by 'n wêreldwye tendens. Die heersende situasie betreffende Skryfkunsopleiding in Suid-Afrika word in twee verwante artikels ondersoek. In Henning Pieterse se 'Die dosering van Skryfkuns aan Suid-Afrikaanse universiteite: 'n Oorsig' word die dosering van Skryfkuns as vak, kursus en/of program aan SuidAfrikaanse universiteite van nader beskou, veral betreffende kursusinhoud, metodologiese en pedagogiese kwessies en uitkomste. Op haar beurt fokus Leti Kleyn op die rol wat skryfopleiding gedurende die tydperk 1995-2012 in die groter Afrikaanse literêre sisteem vervul het, met spesifieke verwysing na skryfopleiding as nagraadse kwalifikasie. Die titel van haar bydrae is: 'Ek dink dis beter vir my skryfwerk om met die regte wêreld te doen te hê': 'n Terreinverkenning van skryfopleiding in die groter Afrikaanse literêre sisteem (1995-2012)'. Hierdie twee artikels toon aan dat Skryfkuns in Suid-Afrika hoofsaaklik op nagraadse vlak gedoseer word. 'n Artikel wat die ander kant van die literêre spektrum belig, is Anneretha Combrink en Annemarie Kruger se bydrae oor die bevordering van woordkuns in gemeenskappe. In dié artikel, 'Multidissiplinêre vennootskappe in gemeenskapseie woordkunsprojekte', word 'n woordkunsprojek in die Rysmierbultomgewing as gevallestudie bespreek met spesifieke aandag aan die dinamiek en waarde van multidissiplinêre vennootskappe in sodanige projekte.

Gepaardgaande met die groei in Skryfkuns is daar ook wêreldwyd 'n groeiende belangstelling in navorsing in Skryfkuns. Franci Greyling se artikel, 'Tinboektoe toe: 'n ruimtelike ontdekkingsreis', ondersoek en illustreer die moontlikhede van praktykgebaseerde navorsingsbenaderings aan die hand van 'n eie kunstenaarsboek. Hierdie projek kan beskou word as 'n geval waarin kunspraktyk die onderwerp, metode, inhoud en uitkoms van navorsing is.

Heelparty van Hans du Plessis se gedigte is getoonset. Bernard Odendaal se bydrae, 'Die raak- en verskilpunte tussen gedigte en liedtekste', sluit daarom op meer as een manier by Hans du Plessis se digterskap aan. Odendaal toon aan dat naas die ritmiese en klankmatige aspekte wat die digkuns met die liedtekskuns in gemeen het, die visuele en beeldende prosodiese elemente onderskeidende kenmerke in die digkuns is. Hy wys voorts hoe veranderinge saamhang met ' $n$ kulturele verskuiwing van die logosferiese na die grafosferiese era.

Hans du Plessis se eie skryfwerk kom onder die soeklig in Marlies Taljard se bydrae, "n Nuwe Groot Trek-mite: Herverbeelding van identiteit in Die pad na Skuilhoek deur Hans du Plessis'. Taljard toon aan hoe Hans du Plessis in sy roman Die pad na Skuilhoek die idee van die geskiedenis as 'n feitelik agterhaalbare reeks gebeure in die verlede ondermyn en dit weer bruikbaar en toepaslik maak vir die hede deur klemlegging op sosiale kwessies wat vir moderne lesers relevant is. In Burgert Senekal se bydrae, "n Netwerkontleding van karakterverhoudinge in Etienne van Heerden se Toorberg', stel hy met behulp van die sosialenetwerk-analise (SNA) ondersoek in na die familiebande in dié roman en demonstreer hoe hierdie nuwe metode ook binne die literatuurstudie toegepas kan word.

In Heilna du Plooy se gesprek met Hans du Plessis, 'Behep met die kompleksiteit van die eenvoud', word die poëtika van die skrywer aan die hand van indringende vrae en antwoorde verhelder.

Die Litera-afdeling bevat kreatiewe werk van Joan Hambidge, Heilna du Plooy, Franci Greyling, Robin Gallaher Branch en Hein Viljoen. 